\title{
ANTI-JEWISH INTERPRETATIONS OF HEBREWS: SOME NEGLECTED FACTORS
}

\author{
Jody A. Barnard*
}

\begin{abstract}
Perhaps one of the most significant developments within contemporary Jewish Studies is the reclamation of the New Testament. The recovery of this particular part of Jewish history, however, has highlighted the problem of anti-Semitism that has for so long been associated with these documents. Although there is nothing as brazen as the Matthean "blood cry" (Mt. 27:25), or the Johannine denouncement of "the Jews" (e.g. Jn. 8:44), Hebrews is often placed among the most antiJewish texts of the New Testament. Key themes contributing to this perception are mainly found in the central section which paints Jesus as the eternal high priest, who offers the definitive means of atonement, and inaugurates the superior new covenant. On the other hand, it is often noted that this "radical supersessionism," as it has been called, must be qualified by the author's own Jewish identity and context, making charges of anti-Judaism, or even anti-Semitism, somewhat misleading, not to mention anachronistic. This paper revisits the anti-Jewish character of Hebrews in the light of recent developments in Jewish and New Testament Studies, showing how the classifications of this text as "anti-Jewish" are not as straightforward as many have supposed.
\end{abstract}

\section{Introduction}

The purpose of this article is to complicate the anti-Jewish interpretations of Hebrews. As we shall see, by the Fourth Century CE the anti-Jewish interpretation of Hebrews was wellestablished, and is plain to see in Chrysostom's influential commentary. While Chrysostom's anti-Jewish rhetoric is of course condemned, many modern interpreters follow his lead (in various ways and degrees) in seeing Hebrews as an anti-Jewish text. Having reviewed a sample of these contributions individually, one from each of the last five decades, we shall then discuss four factors that they all fail to assimilate adequately, and that further complicate the anti-Jewish interpretation of Hebrews.

\section{Is Hebrews Anti-Jewish?}

For many interpreters, past and present, the answer to this question is obvious and affirmative. Naturally, there are many factors behind, in, and in front of, the text that influence this judgment, but for our present purposes I shall focus on the text in its ancient context. The most regularly identified anti-Jewish statements in Hebrews are as follows. ${ }^{1}$

\footnotetext{
" Independent Scholar. Currently researching ancient Jewish mysticism, and working as a private tutor. Email: jodyb@biblicalgreektuition.co.uk

${ }^{1}$ All translations are my own, unless noted otherwise.
} 
Therefore, if God's ultimate objective had been accomplished ( $\tau \varepsilon \lambda \varepsilon i \omega \sigma 1 \varsigma)$ through the Levitical priesthood - on the basis of which the people were legally bound - what need would there have been to speak about another priest arising in the order of Melchizedek [Ps. 110:4], and not in the order of Aaron? For when the priesthood is changed, it is necessary to change the law also ... For, on the one hand, a former commandment is being set aside ( $\dot{\alpha} \theta \dot{\varepsilon} \tau \eta \sigma 1 \varsigma)$, because it is weak $(\dot{\alpha} \sigma \theta \varepsilon v \varepsilon \dot{\varepsilon} \zeta)$ and ineffective ( $\dot{\alpha} v \omega \varphi \varepsilon \lambda \dot{\varepsilon} \varsigma)$ - for the law brought nothing to completion - but, on the other hand, a better hope is brought in alongside, through which we are drawing near to God. (7:11-12, 18-19)

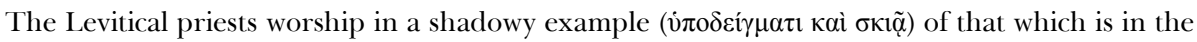
heavens, for when Moses was about to construct the tabernacle he was told to "pay attention" and to "make everything according to the design shown to you on the mountain" [Ex. 25:8-9]; but now Jesus has obtained a superior ministry, insofar as he is a mediator of a better covenant,

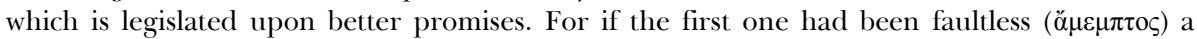
place would not have been sought for a second one ... By speaking about a new covenant [Jer. 31:31-34], God made the first one old, and that which is old and aging is near to vanishing ( $\dot{\varepsilon} v$

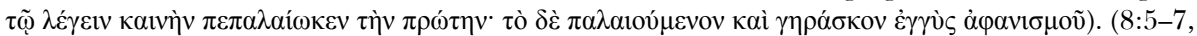
13)

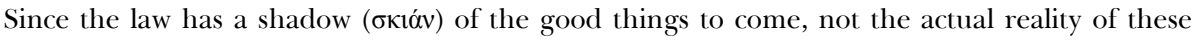
things, it can never, by the same sacrifices that are continually offered year after year, complete those who approach ... When he says "you did not want and were not pleased with sacrifices and offerings, whole burnt offerings and sin offerings" - which are offered according to law and then says "here I am to do your will" [Ps. 40:7-9], he takes away the first in order to

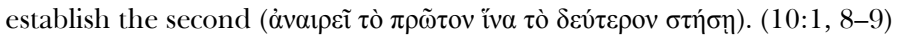

Unlike some English translations, I have endeavoured to avoid augmenting the antiJewish potential of these verses, but it nevertheless remains clear that assessments of Hebrews as a "discourse of anti-Judaism," 2 as one recent author put it, are not without basis. In fact, this perspective is the predominant one and has a long lineage. It was wellestablished by the Fourth Century CE, as Chrysostom's Homilies on Hebrews, the earliest comprehensive commentary on Hebrews to have reached us, indicates.

Our high priest is on high, and is much better than those Jewish priests, not only in this way, but also with regard to place, tabernacle, covenant, and person ... it is good then for those who have this great priest to be superior, and for the difference between us and the Jews to be as great as that between Christ and Aaron. Therefore, consider that we have an offering on high, a priest on high, a sacrifice on high. So let us offer sacrifices that can be brought to that altar, not sheep and cows, not blood and burning fat, all these things have been abandoned $(\lambda \varepsilon \dot{\lambda} \lambda \tau \tau \alpha)$,

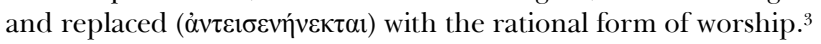

By saying "according to the order of Melchizedek" [Heb. 7:11], he expels ( $\dot{\varepsilon} \xi \dot{\varepsilon} \beta \alpha \lambda \varepsilon v)$ the order of Aaron ... He became a priest, he says, not according to the law of a carnal commandment

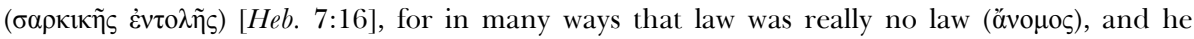
spoke well when he called it a carnal commandment, for all things were limited to the carnal

2 A. M. Bibliowicz, Jews and Gentiles in the Early Jesus Movement: An Unintended Journey (New York: Palgrave Macmillan, 2013), 131.

${ }^{3}$ John Chrysostom, Homily 11; J.-P. Migne, ed., Patrologia Graeca, 161 vols. (Paris: Migne, 1857-86) 63, 92. Henceforth $P G$. 


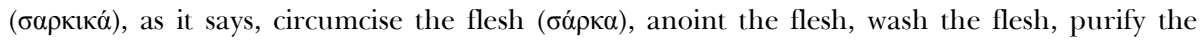
flesh, shave the flesh, fasten on the flesh, take care of the flesh, laze in the flesh ... He says that "the previous commandment has been set aside ( $\dot{\alpha} \theta \dot{\varepsilon} \tau \eta \sigma ı \varsigma)$, because it was weak $(\dot{\alpha} \sigma \theta \varepsilon v \dot{\varepsilon} \varsigma)$ and

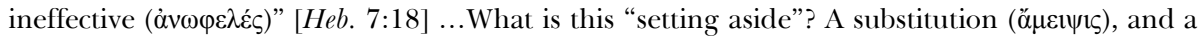

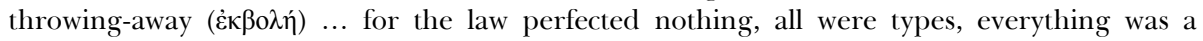
shadow, be it circumcision, sacrifice, or Sabbath. ${ }^{4}$

Similarly, there are a number of references to Hebrews in Chrysostom's notorious Orations Against the Jews, or Orations Against Judaizing Christians, since his primary targets are those among his own congregation who were observing Jewish customs (keeping the Sabbath, attending the synagogue, and participating in the various fasts, feasts, and festivals). ${ }^{5}$ In his seventh speech, for example, he describes the fasts, feasts, and festivals of the Jews as abominations that are contrary to the purposes of God, claiming that the entire Jewish

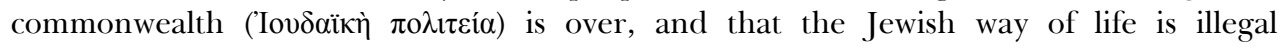
$(\pi \alpha \rho \alpha v$ ó $\mu \omega \varsigma)$. Among the "proofs" for these suppositions are numerous references to the central section of Hebrews, a text which he describes as a severe blow ( $\pi \lambda \eta \gamma \eta$ ) to the Jews in that it demonstrates the futility ( $\left.\dot{\alpha} \varepsilon \lambda \eta \varsigma_{\varsigma}\right)$ of their commonwealth and God's rejection ( $\dot{\alpha} \omega \dot{\sigma} \sigma \alpha \tau)$ of it in favour of the new way inaugurated by Christ. ${ }^{6}$

In the hands of Chrysostom Hebrews is a radical statement of wholesale supersessionism in which Jews and Judaism have been discarded, and replaced with Christians and Christianity. As far as Chrysostom was concerned, there was a firm boundary between Judaism and Christianity, and any blurring of this boundary was regarded as a grievous sin. Given that Chrysostom had to preach his Orations Against Judaizing Christians at all suggests that a significant portion of his congregation did not take his anti-Jewish views very seriously, but such anti-Jewish interpretations of Hebrews quickly became commonplace, and remained unchallenged until very recently.

In the wake of the Shoah, as interest in the problem of anti-Semitism increased, many have turned to the specific problem of anti-Semitism in the New Testament. As Lloyd Gaston's memorable summary goes, "A Christian church with an anti-Semitic New Testament is abominable, but a Christian church without a New Testament is inconceivable." 7 It is hard to imagine anyone denying the presence of at least some kind of anti-Semitism in the Church Fathers. As we have just observed, there can be no doubt about Chrysostom's anti-Jewish rhetoric. Neither can there be any doubt about his use of New Testament texts to this end. The question is the extent to which, if at all, such invective can be found in the New Testament itself. In the remainder of this paper I shall outline some of the contours of this ongoing discussion as it relates to Hebrews by focussing on five studies, one from each of the last five decades. The first three (Ruether, Gager, and Wilson) are chosen because they belong to major studies of Christian antiSemitism that have since become well known and influential. The other two are chosen because one (Kim) is the first (and currently only) full-length analysis of the issue in Hebrews, and the other (Bibliowicz), written from a Jewish perspective, is the most recent.

\footnotetext{
${ }^{4}$ John Chrysostom, Homily 13; PG 63, 103-105.

${ }_{5}^{5}$ P. W. Harkins, St. John Chrysostom: Discourses Against Judaizing Christians (Washington D.C.: Catholic University of America Press, 1979).

${ }^{6}$ John Chrysostom, Adversus Judaeos 7; PG 48, 915-928.

${ }^{7}$ L. Gaston, Paul and the Torah (Vancouver: University of British Columbia Press, 1987), 15.
} 


\section{Rosemary Ruether's "Faith and Fratricide"}

In Rosemary Ruether's influential book, Faith and Fratricide, she argues that the adversus Judaeos traditions of the Church Fathers are rooted in the earliest form of Christianity. ${ }^{8}$ For Ruether, anti-Judaic thought is the "left hand" of Christology, as she famously put it, and is embedded in the New Testament itself. With regard to Hebrews, she maintains that Chrysostom was simply following Hebrews' lead, ${ }^{9}$ and she understands Hebrews itself as a fusion of spiritualizing and eschatological exegesis in which ...

Judaism is not merely superseded historically, but absolutely. It is the mere finite, mutable and carnal, in contrast to the eternal, immutable and spiritual ... The people who cling to this religion, and imagine thereby to win God's approval, belong to the heritage of apostasy. ${ }^{10}$

By asserting that the "author is a pastor addressing a Jewish Christian community, probably in Alexandria, which is in danger of backsliding into Judaism," 11 she is in tune with the traditional, and still widespread, paradigm for interpreting Hebrews, which is at least as old as Chrysostom. ${ }^{12}$ Thus, she is in broad agreement with Chrysostom's interpretation of Hebrews, which, along with the rest of the anti-Jewish arguments of the New Testament and the Church Fathers, she argues led to the tragic history of the Jews in Christendom, and formed the foundation for political and social anti-Semitism.

Ruether's book makes a powerful point, and rightly called for a new consciousness among Christians that acknowledges and questions its anti-Jewish history and theology. Although she has certainly identified a key issue in Jewish-Christian relations, it is doubtful that Christology can bear the weight that she has placed upon it. After all, the first people to proclaim Jesus as the Messiah were Jews, and in the years following Ruether's book it has been demonstrated that many of the exalted claims about Jesus in the New Testament documents have an essentially Jewish character, and likely emerged from a Jewish context. ${ }^{13}$ Christology can of course operate in an anti-Jewish manner, as Ruether has demonstrated, but it is premature to imagine such a sharp distinction between Jews and Christians in the New Testament, and it is misleading to identify this single issue as the point of contention between them. Ruether seems to acknowledge this latter point with regard to Hebrews when she notes that "the real concerns of the christological exegesis of Hebrews center on the temple cultus." 14 The essential continuity that she sees between Chrysostom and Hebrews is a question to which we shall return. ${ }^{15}$

\footnotetext{
${ }^{8}$ R. R. Ruether, Faith and Fratricide: The Theological Roots of Anti-Semitism (New York: Seabury Press, 1974).

${ }^{9}$ Ibid., 158-159, 164.

${ }^{10}$ Ibid., 107, 110 .

${ }^{11}$ Ibid., 110.

12 Although Chrysostom believed the destination to be "Jerusalem and Palestine" $(P G 63,11)$.

${ }^{13}$ E.g. A. F. Segal, Two Powers in Heaven: Early Rabbinic Reports about Christianity and Gnosticism (Leiden: Brill, 1977), L. W. Hurtado, One God, One Lord: Early Christian Devotion and Ancient Jewish Monotheism (2nd ed., Edinburgh: T\&T Clark, 1998); J. D. G. Dunn, Christology in the Making: A New Testament Inquiry into the Origins of the Doctrine of the Incarnation (2nd ed., London: SCM Press, 1989); A. Chester, Messiah and Exaltation: Jewish Messianic and Visionary Traditions and New Testament Christology (Tübingen: Mohr Siebeck, 2007); D. Boyarin, The Jewish Gospels: The Story of the Jewish Christ (New York: New Press, 2012).

${ }_{14}$ Ruether, Faith and Fratricide, 109.

${ }^{15}$ See also A. T. Davies, ed., Antisemitism and the Foundations of Christianity (New York: Paulist, 1979).
} 


\section{John Gager's "Origins of Anti-Semitism"}

Another attempt at tracing the origins of anti-Semitism is that of John Gager. ${ }^{16}$ Gager begins by noting that the discussion of "anti-Semitism" has been hampered by confusing and ill-defined terminology, which he seeks to clarify. He retains the term "anti-Semitism" to denote "hostile statements about Jews and Judaism on the part of Gentiles," explaining that such statements are expressed by uninformed outsiders, and bear some resemblance to what we call anti-Semitism today. This is distinguished from the early Christian hostilities, for which he adopts the term "anti-Judaism," which is a variegated "matter of religious and theological disagreement." 17 In tracing the role of Christianity in the origins of anti-Semitism, Gager maintains that the early intra-Christian debates over the presence and extent of Judaism in Christianity produced a body of literature that was selectively preserved in accordance with the anti-Jewish tendencies of the eventual victors, and subsequently interpreted in anti-Jewish ways. Gager focuses his discussion on Paul (whom he distinguishes from his later anti-Jewish commentators) but also accommodates some passing reflections on Hebrews.

Like Ruether, Gager understands Hebrews as an essentially anti-Jewish text. He asserts, for example, that Hebrews "reflects the general preoccupation of Christian-writers in the late first century with demonstrating the absolute superiority of Christianity over Judaism," and describes it as an "extended polemic" against "involvement in Jewish beliefs and practices." 18 Although he remains agnostic over whether the addressees are JewishChristians tempted to return to Judaism, or Gentile Christian Judaizers, he believes that "it offers the most sustained and systematic case against Judaizing to be found anywhere in Christian literature of the first century." ${ }^{19}$ Unlike Ruether, however, he makes an important distinction. Gager rightly observes that "Hebrews says nothing at all about the Jews as such and shows no inclination to identify the recipients of the new covenant as Gentiles," and goes on to conclude that "the target of the polemic is Judaism per se rather than the Jews as a people." 20 Although it is debateable just how helpful this distinction is, at least it shows some effort to appreciate what the text does and does not say. Nevertheless, while rejecting the specific charge of anti-Semitism on behalf of Hebrews, he is clear that it belongs to the anti-Jewish wing of Christian literature, akin to Barnabas and Ignatius, and "well on the way to Marcion." 21

\section{Stephen Wilson's "Related Strangers"}

Similarly, in his survey of Jewish-Christian relations from 70-170 C.E., Stephen Wilson also concludes that Hebrews is a severe example of anti-Judaism, although he is somewhat

\footnotetext{
${ }^{16} \mathrm{~J}$. G. Gager, The Origins of Anti-Semitism: Attitudes Toward Judaism in Pagan and Christian Antiquity (Oxford: Oxford University Press, 1983).

${ }^{17}$ Ibid., 8; cf. D. R. A. Hare, "The Rejection of the Jews in the Synoptic Gospels and Acts," in Antisemitism, ed. Davies, 28-32.

${ }^{18}$ Ibid., 181, 182.

${ }^{19}$ Ibid., 184.

${ }^{20}$ Ibid., 183.

${ }^{21}$ Ibid.
} 
more confident about its exclusively Gentile background. ${ }^{22}$ Wilson argues that, like Barnabas, Hebrews sets forth a radical statement of supersession in which Christians have replaced the Jews as the new people of God. ${ }^{23}$ According to Wilson, the theology of Hebrews "routinely and starkly contrasts Christianity and Judaism to the detriment of the latter"; although certain heroes from Israel's past are portrayed positively, "Israel is castigated and superseded." ${ }^{24}$ Wilson believes that this radical supersessionism was provoked by Gentile Judaizers who set the author on a course of intra-Christian selfdefinition over and against Judaism. ${ }^{25}$ In view of this, it might be argued that the supersessionism of Hebrews is merely a by-product of Christian self-assertion, and is in no way anti-Jewish, ${ }^{26}$ but Wilson rejects such attempts to minimise the anti-Jewish attitudes expressed in Hebrews, maintaining that the author knew exactly what he was doing, and that his "gratuitous denigration" of Judaism "takes up as much space as the more positive assertions," suggesting that Judaism "was an immediate threat." 27 Neither is he convinced by those who argue that there is no polemic against Judaism in Hebrews because it is not Jews, but Christians who are addressed. ${ }^{28}$ In response, Wilson rightly notes that there is no reason to restrict the categories of "polemic" and "anti-Judaism" to situations of head-on conflict since "they can appear in an entirely Christian environment." 29

In his review of Wilson's book, which is generally very positive, Neusner notes a gaping flaw, ${ }^{30}$ namely, that despite acknowledging the great diversity among Jews and Christians, and the extraordinary range and complexity of Jewish-Christian relations, Wilson often speaks about Jews and Christians as if they were two well-defined groups, and Judaism and Christianity as if they were two well-defined religions. ${ }^{31}$ This is also evident throughout his discussion of Hebrews which repeatedly asserts a sharp contrast between two coherent abstractions that did not exist at this time, with Jews and Judaism, on the one hand, and Christians and Christianity on the other. Although his interpretation of specific details might (or might not) be correct, the extent to which Wilson's discernment of a "radical supersessionism" depends upon these abstractions has a direct bearing on the extent to which his reconstruction unravels.

One area in which this seems to unravel concerns the author's characterization of his group as the "descendents of Abraham" (Heb 2:16), which Wilson asserts, without argument, means that "they are Christians, not Jews." 32 As Wilson is perfectly aware, these categories are not mutually exclusive, yet this seems to be the assumption guiding the distinction, as if "Christian" was synonymous with "Gentile." More importantly, however, Hebrews provides no basis for interpreting this phrase typologically as a reference to Christian Gentiles, as Paul does in Galatians, for example. The author of Hebrews consistently treats Abraham as a historical individual, so when he refers in passing to his

${ }_{22}^{2}$ S. G. Wilson, Related Strangers: Jews and Christians, 70-170 C.E. (Minneapolis, Minnesota: Fortress Press, 1995).

${ }^{23}$ Ibid., 110-142.

${ }^{24}$ Ibid., 117, 119

25 Ibid., 123-127.

${ }^{26}$ E.g. E. Grässer, “Der Hebräerbrief 1938-1963,” TR 30 (1964), 149.

${ }^{27}$ Wilson, Related Strangers, 122.

${ }^{28}$ E.g. G. Hughes, Hebrews and Hermeneutics (Cambridge: Cambridge University Press, 1979), 54-55.

${ }^{29}$ Wilson, Related Strangers, 122.

${ }^{30}$ J. Neusner, "Judaism and Christianity in the Beginning: Time for a Category-Reformation?," BBR 8 (1998), 229-237.

${ }^{31}$ Ibid., 234-237.

${ }^{32}$ Wilson, Related Strangers, 118. 
brothers as the "seed of Abraham" ( $\sigma \pi \varepsilon \dot{\varepsilon} \mu \alpha$ A $A \rho \alpha \alpha \dot{\alpha} \mu)$, it naturally bears its ordinary meaning, and seems to mark the specifically Jewish identity of these particular followers of Jesus (cf. Is. 41:8-10; Ps. Sol. 9:9; 18:3; 3 Macc. 6:3; 2 Cor. 11:22). ${ }^{33}$ As the ascription "to the Hebrews" (from the late Second Century onwards) suggests, and as most scholars maintain, they regarded themselves as part of the same house as Moses (Heb 3:1-6), that is, the house of Israel (8:8-10), and direct descendents of the Patriarchs and the Prophets $(1: 1 ; 7: 4 ; 11: 2){ }^{34}$ Although certainty is out of the question, on balance, the addressees are most likely somewhere within the spectrum of ancient Jewish society.

\title{
4. Lloyd Kim's "Polemic in the Book of Hebrews"
}

The first monograph length study to tackle the anti-Jewish character of Hebrews is Lloyd Kim's Polemic in the Book of Hebrews. ${ }^{35}$ In this book Kim offers a socio-rhetorical analysis of Hebrews and begins by reconstructing the social context of the author of Hebrews and its recipients. Kim maintains that the community behind Hebrews is a Jewish-Christian sect "distinguished from and marginalized by the dominant Jewish society," and that the author is engaged in a form of counter-cultural rhetoric that seeks to legitimize his community over and against the dominant form of Judaism. ${ }^{36}$ The core of Kim's study is an attempt to examine the meaning and function of the author's polemic against the Levitical priesthood (7:1-19), the Mosaic covenant (8:1-13), and Levitical sacrifices (10:110 ), in light of the larger context of late Second Temple Judaism, and to determine whether Hebrews itself is anti-Semitic, anti-Judaic, or supersessionistic.

In short, Kim concludes that these institutions played an important role in the life and identity of the Jewish people, and that the criticisms in Hebrews signal a radical discontinuity with the Judaism of the day.

\begin{abstract}
The author was seeking to persuade those who were tempted to revert back to Judaism to remain faithful to his community, while strengthening and confirming the commitment of those who did remain. His polemic against the Levitical priesthood and law, Mosaic covenant, and Levitical sacrifices functions to legitimize his community and further distinguish it from the dominant Jewish society. ${ }^{37}$
\end{abstract}

Kim notes that although there is much ancient intra-Jewish denigration with which the polemic in Hebrews may be compared, Hebrews goes further in criticizing the sacred institutions themselves, whereas others merely criticize the abuses of these institutions. Kim also argues that this radical discontinuity is balanced by an essential continuity in that the author retains the history and legacy of Israel, bases his Jewish arguments on the Jewish

\footnotetext{
${ }^{33}$ See C. P. Anderson, "Who are the Heirs of the New Age in the Epistle to the Hebrews," in Apocalyptic and the New Testament: Essays in Honour of J. Louis Martyn, eds. J. Marcus and M. L. Soards (JSNTSup 24; Sheffield: JSOT Press, 1989), 255-277.

${ }^{34}$ E.g. G. L. Cockerill, The Epistle to the Hebrews (NICNT; Grand Rapids, Michigan: Eerdmans, 2012), 19-23; P. Ellingworth, The Epistle to the Hebrews (NIGTC; Grand Rapids, Michigan: Eerdmans, 1993), 21-27.

35 L. Kim, Polemic in the Book of Hebrews: Anti-Judaism, Anti-Semitism, Supersessionism? (Eugene, Oregon: Pickwick Publications, 2006).

36 Ibid., 17-61.

${ }^{37}$ Ibid., 198.
} 
Scriptures, and is writing about new Jewish institutions that are the eschatological culmination of old Jewish institutions for the benefit of the Jewish people. Like Gager and others, Kim distinguishes between "anti-Semitism" and "anti-Judaism," and, noting its nineteenth-century origins and ethnic and racial contours, rejects the former term as an adequate description of Hebrews. He emphasizes that Hebrews addresses theological differences among Jews, and concludes that "the polemical passages in Hebrews do not promote hatred of the Jews, nor do they advocate the destruction of the Jewish people." 38 Kim does regard Hebrews as "anti-Judaic," however, "in the sense that it speaks of the fulfilment of the Levitical priesthood and law, the Mosaic covenant, and the Levitical sacrifices," and talks of a "qualified supersessionism," explaining that the "author is not arguing for the abandonment by God of the Jewish people, but rather for the abandonment of the shadowy means by which God's people draw near to him." 39

This is a well-conceived contribution which definitely advances the discussion, although, in my opinion, there are a number of points where it could be nuanced a little more carefully. First, as a socio-rhetorical interpretation Kim's analysis relies heavily upon a reconstruction of the social context behind the text, ${ }^{40}$ a hazardous task at the best of times, but especially in the case of Hebrews. This is not simply because there is so little information about the social context given in the text itself, ${ }^{41}$ but because Hebrews is largely preoccupied with heavenly and future realities, all of which are expressed with scriptural vocabulary and imagery. It is interesting to note just how many of the factors involved in Kim's reconstruction of the social context of Hebrews are inextricably caught up with the exegesis, mysticism, and eschatology of Hebrews. ${ }^{42}$ While it is difficult to interpret Hebrews without at least some idea of its immediate social context, one should be aware that the reconstruction of social realities from the text of Hebrews risks transforming that which the author regarded as the world to come into the world behind the text. This criticism could of course be applied to all the studies discussed here, and more besides, but it is particularly acute in a socio-rhetorical analysis.

Second, although Kim's analysis of Second Temple Jewish literature recognizes the variety therein, this variety tends to be treated as a unity in the comparison with Hebrews, as if two things are being compared, when in fact multiple things are being compared. Moreover, although he gathers a healthy cross-section of texts on which to base his reconstruction of ancient Jewish thought, the basis on which they are selected is unclear, and one might query how an examination of the texts that are not included in Kim's study (such as the Enoch literature for example) might nuance the picture further. Therefore, all statements about how alarming Hebrews would have sounded "to Jewish ears" or within "mainstream Judaism" may need to be nuanced a little more carefully to account for the variegated spectrum of ancient Jewish sensibilities. ${ }^{43}$

${ }^{38}$ Ibid., 201

${ }^{39}$ Ibid., 200, 201.

${ }^{40}$ Ibid., 17-61 (approximately a quarter of the book).

${ }^{41}$ A point well made by Pamela Eisenbaum, "Locating Hebrews within the Literary Landscape of Christian Origins," in Hebrews: Contemporary Methods - New Insights, ed. G. Gelardini (Leiden; Boston: Brill, 2005), 213-237.

${ }^{42}$ Kim, Polemic, 49-52.

${ }^{43}$ Ibid., 47, 81, 122, 180, 199. 
Third, Kim simply assumes a pre-70 date for Hebrews, and takes it for granted that the audience have access to an operational Levitical cultus. ${ }^{44}$ Kim provides no explanation as to why he prefers a pre-70 date over an equally possible post-70 date, even though it has a direct bearing on the meaning and significance of the polemic in Hebrews. As Mark Nanos explains,

It seems to me that the Levitical priestly service is no longer available to the author and addressees ... they are unable to avail themselves of its sacrificial services for sins, and therefore they are experiencing insecurity. If so, then the language pointing to a superior way to achieve this outcome through the faith of/in Christ Jesus can be understood as one Jewish group's way of dealing with a matter that the former covenantal arrangements no longer offered to them ... But if partaking of that system is still open to them and they are being told to abandon it as bankrupt because there is now a new and better way that makes that covenantal behaviour obsolete or counter-faithful, then it would seem to represent a new religious movement. ${ }^{45}$

A post-70 reading of Hebrews, therefore, casts its comments in a somewhat different light, but Kim neglects to examine this. Rather than interpreting Hebrews as a radical rejection of something dear to the Jewish people that distinguishes it from Judaism, it might be interpreted as a message of encouragement to those distressed by the loss of the Levitical cultus; a reassurance that God has provided another way to live in covenantal faithfulness that renders the Levitical system superfluous. ${ }^{46}$ It is still radical, but, like 4 Ezra, 2 Baruch, and 3 Baruch, it could be located within the spectrum of Jewish responses to the sack of Jerusalem and destruction of the Temple.

\section{Abel Bibliowicz's "Jews and Gentiles in the Early Jesus Movement"}

To my knowledge, the most recent analysis of anti-Jewish attitudes in Hebrews is that of Abel Bibliowicz who mostly reiterates Stephen Wilson's position, albeit with an extra emphasis on the exclusively Christian and Gentile parameters of the author's situation. ${ }^{47}$ Bibliowicz stresses that "there is nothing in the epistle that necessitates the assertion that the author's concerns, adversaries, audience, or horizon are outside the Jesus movement," 48 and argues that Hebrews reflects "a debate among Gentile believers in Jesus about continuity-discontinuity vis-à-vis the founding fathers." 49 Thus, according to Bibliowicz, "the author does not aim at Judaism per se," ${ }_{50}$ the "apostasy" in question is not an attraction to "external-mainstream Judaism," but to the beliefs and traditions of Jesus' first followers, and that "from among all the New Testament writers, Hebrews moves

\footnotetext{
44 E.g. "The author's polemic against the Old Testament sacrifices functions to dissuade his readers from participating in them" (ibid., 189).

${ }_{45}$ M. D. Nanos, "New or Renewed Covenantalism? A Response to Richard Hays," in The Epistle to the Hebrews and Christian Theology, eds. R. Bauckham et al. (Grand Rapids, Michigan; Cambridge, UK: Eerdmans, 2009 ), 185.

${ }^{46}$ E.g. M. E. Isaacs, Sacred Space: An Approach to the Theology of the Epistle to the Hebrews (JSNTSup 73; Sheffield: JSOT/Sheffield Academic Press, 1992).

${ }_{47}$ Bibliowicz, Jews and Gentiles, 115-137.

48 Ibid., 117.

49 Ibid., 119.

${ }^{50}$ Ibid., 134. Gager asserts the exact opposite (see above).
} 
furthest in the direction of a breach with the traditions of Jesus's companions." ${ }^{11}$ Like Wilson, Bibliowicz maintains that the intra-Christian nature of the conflict in no way alleviates its anti-Jewish rhetoric, and describes Hebrews as "the cornerstone of supersession theology," a "discourse of anti-Judaism" that is "highly abusive to Jewish sensibilities." ${ }_{52}$

Overall, Bibliowicz's book serves as a valuable reminder of the anti-Jewish character, and anti-Semitic potential, of much Christian theology, culture, and lore, but unfortunately his analysis of Hebrews offers little grist for the mill. That the author's horizon is within the Jesus movement is not in dispute, and it is unclear what difference it really makes to stress that he is arguing against the Jewish traditions of Jesus' first followers, rather than simply asserting, like the other studies we have discussed, that he is arguing against Jewish traditions, traditions that were of course observed by Jesus and his first followers, but also by the rest of Jewish society, in various ways and degrees. Bibliowicz's emphasis of this point may suggest that he is drawing too sharp a distinction between the variegated Jesus movement and the variegated Judaism of which it was a part. Neither does he appreciate the distinctions developed by Gager and Kim, but simply forces Hebrews into his meta-narrative of a "Pauline-Lukan" or "proto-orthodox" faction, stating that from "Hebrews onward Pauline-Lukan Gentiles perceived themselves as replacing 'the Jews' as YHWH's chosen." ${ }^{33}$ In the end, Bibliowicz's examination of Hebrews largely restates Stephen Wilson's assessment, and fails to engage with the most significant contributions from the last decade or so. ${ }^{54}$

\section{Some Neglected Factors}

Significantly, each of the five studies reviewed above agrees that Hebrews is anti-Jewish. Although the extent and nature of its anti-Judaism and supersessionism are variously conceived, like Chrysostom, they regard Hebrews as a radical blow to the heart of Judaism. We have already begun to note some of the individual limitations and weaknesses in these proposals, all of which serve to complicate their anti-Jewish interpretations of Hebrews. The remainder of this paper will discuss a further four factors that they all fail to assimilate adequately or neglect altogether.

\section{Multiple Ways, Fuzzy and Fused}

The idea of a single, early, and decisive separation between the two "religions" of "Judaism" and "Christianity" has been fought, and overcome, on many fronts. ${ }^{55}$ Although we may encounter various localized, isolated, and literary incidents of separation and

\footnotetext{
${ }^{51}$ Ibid., 129.

${ }^{52}$ Ibid., 137, 131, 134.

${ }^{53}$ Ibid., 121.

${ }^{54}$ E.g. Kim, Polemic; Gelardini, ed., Hebrews; Bauckham et al., eds., Epistle to the Hebrews.

${ }_{55}$ E.g. A. H. Becker and A. Y. Reed, eds., The Ways that Never Parted: Jews and Christians in Late Antiquity and the Early Middle Ages (Tübingen: Mohr Siebeck, 2003); cf. H. Shanks, ed., Partings: How Judaism and Christianity Became Two (Washington D.C.: BAS, 2013).
} 
opposition between "Jews" and "Christians," it is doubtful that we can speak very much of two distinct ways prior to Rome's patronage of the Church. ${ }^{56}$ As Jacob Neusner succinctly puts it, "Judaism and Christianity as they would live together in the West met together for the first time in the fourth century." 57 It is highly dubious, therefore, when Chrysostom appeals to a three-hundred year old text in support of a recent, and still emerging, division between Judaism and Christianity. Similarly, it is equally dubious when Ruether imagines the author to be asserting "an absolute line" between Judaism and Christianity, ${ }^{58}$ or when Gager declares that Hebrews is preoccupied "with demonstrating the absolute superiority of Christianity over Judaism." ${ }^{59}$ Such assumptions are anachronistic with respect to Hebrews, and have led to hasty conclusions regarding the place of Hebrews in relation to the Judaism of the day.

As we now know, first-century Judaism was a complex affair, leading some to speak about Judaisms rather than Judaism. ${ }^{60}$ Although the usefulness of the plural is debateable, its use effectively illustrates the fallacy that ancient Judaism was some kind of rigid structure that flowed seamlessly into the rabbinic era. As Seth Schwartz notes, "it is difficult to imagine any serious scholar ever again describing the Judaism of the later Second Temple period as a rigorous, monolithic orthodoxy, as was still common only a generation ago." ${ }^{1} 1$ Although he rejects the characterization of ancient Judaism as multiple, Schwartz takes it for granted that it "was complex, capacious, and rather frayed at the edges," and observes the "messiness, diversity, and unpredictability" that might ensue within a coherent ideology of "the one God, the one Torah, and the one Temple." 62 In spite of the great diversity, however, many scholars maintain that it is still possible to speak of a "common Judaism," 63 based on certain distinguishing characteristics that unite the various strands. Martin Goodman, for instance, suggests that Rabbi Yohanan's estimate of twentyfive types of Judaism prior to the destruction of the Temple (j. Sanh. 29c) is "just about right," but nevertheless rejects the view that there was no common core in late Second Temple Judaism, explaining that "All pious Jews shared at least the beliefs that they worshipped the God whose Temple was in Jerusalem and that they had a common history in which a covenant between God and Israel was enshrined in the Torah, which all Jews knew they had to observe." 64 Although it may be misguided to insist on any single feature as essential to the Judaism of the period, ${ }^{65}$ the following four themes, identified by Ed

${ }_{56}$ P. Alexander, “The Parting of the Ways' from the Perspective of Rabbinic Judaism," in Jews and Christians: The Parting of the Ways, ed. J. D. G. Dunn (Tübingen: J. C. B. Mohr (Paul Siebeck), 1992), 1-25; J. Lieu, "'The Parting of the Ways': Theological Construct or Historical Reality?," JSNT 56 (1994), 101-119.

${ }^{57} \mathrm{~J}$. Neusner, Judaism and Christianity in the Age of Constantine (Chicago: University of Chicago Press, 1987), ix.

${ }_{58}$ Ruether, Faith and Fratricide, 111.

${ }^{59}$ Gager, Origins, 181.

${ }^{60}$ E.g. J. Neusner, W. S. Green, and E. S. Frerichs, eds., Judaisms and their Messiahs at the Turn of the Christian Era (Cambridge: Cambridge University Press, 1987).

${ }^{61}$ S. Schwartz, Imperialism and Jewish Society 200 B.C.E. to 640 C.E. (Princeton: Princeton University Press, 2001), 45 .

62 Ibid., 9, 49.

${ }^{63}$ E.g. E. P. Sanders, Judaism: Practice and Belief, 63 BCE-66 CE (Corrected ed., London: SCM; Philadelphia: Trinity Press International, 1994); G. Stemberger, "Was There a 'Mainstream Judaism' in the Late Second Temple Period?," Review of Rabbinic Judaism 4.2 (2001), 189-207; W. O. McCready and A. Reinhartz, eds., Common Judaism: Explorations in Second-Temple Judaism (Minneapolis, Minnesota: Fortress Press, 2008).

${ }_{64}$ M. Goodman, Judaism in the Roman World (Leiden: Brill, 2007), 46, 34 n. 3.

${ }^{65}$ J. Z. Smith, "Fences and Neighbours: Some Contours of Early Judaism," in Approaches to Ancient Judaism, ed. W. S. Greed, vol. 2 (Chico, California: Scholars Press, 1980), 1-25. 
Sanders as common to the "vast majority of Jews in the ancient world," provide a solid enough basis for determining these distinguishing characteristics.

(1) Belief in and worship of the God of Israel;

(2) Acceptance of the Jewish Scriptures as revealing his will;

(3) Obedience to at least some aspects of the Mosaic Law;

(4) Identification with the history and fate of the Jewish people. ${ }^{66}$

These themes could be unpacked further of course, but are sufficient to say that, despite the veritable consensus regarding the immense diversity within Second Temple Judaism, it seems that we may also, at the very least, speak of "a shifting cluster of characteristics" that would have identified the various groups and sects as Jewish. ${ }^{67}$

The same could be said of the early Jesus movement of course, a model of "interactive diversity" (pace Eusebius, Hist. eccl. 3.32.8), ${ }^{68}$ yet united by its focus on Jesus of Nazareth, but when we encounter the New Testament documents, it has not always been appreciated that we are often dealing with further varieties of ancient Jewish literature that are just as much a part of Jewish history, as they are Christian history, as the recent reclamation of the New Testament within Jewish Studies acknowledges. ${ }^{69}$ Thus, rather than approaching these documents from the perspective of two "parted ways," which is to pre-judge the evidence anachronistically, it is more appropriate to start with "multiple ways, fuzzy and fused" as an interpretative paradigm, and situate the variegated Jesus movement of the First Century within the equally variegated Judaism of the late Second Temple period. What we have in the First Century is a number of connected currents, all fiercely debating the interpretation of Torah..$^{70}$

With regard to Hebrews then, a document emerging sometime between 60 and $100 \mathrm{CE}$ among "descendents of Abraham" (Heb 2:16; see above), which presupposes the authority of the Jewish Scriptures and the God of Israel, it is probably more appropriate to approach Hebrews as an example of the diverse literature of Hellenistic Judaism.

From this perspective, and from the perspective of its author, Hebrews is a piece of ancient Jewish literature that bears witness to and argues fiercely for a particular form of ancient Judaism. Therefore, all talk of Hebrews as a Christian homily against "(re)lapsing" into Judaism (so Ruether, Gager, Wilson, and Kim) ${ }^{71}$ is misguided and misleading. When Hebrews first emerged, the world at large was predisposed to judge it as Jewish literature. Within Jewish society, the reception of Hebrews would no doubt have been as diverse as the Judaism from which it emerged. Unfortunately, we do not know how Hebrews was initially received - we know how it was subsequently received, in a Gentile Church that defined itself in increasingly anti-Jewish ways - but it is probably safe to speculate that it

\footnotetext{
${ }^{66}$ E. P. Sanders, "Common Judaism Explored,” in Common Judaism, eds. McCready and Reinhartz, 18.

${ }^{67}$ Smith, "Fences and Neighbours," 1-25.

${ }^{68}$ L. Hurtado, "Interactive Diversity: A Model of Christian Origins," JTS 64.2 (2013), 445-462.

${ }^{69}$ E.g. A.-J. Levine and M. Z. Brettler, eds., The Jewish Annotated New Testament (Oxford: Oxford University Press, 2011).

${ }^{70}$ See L. T. Johnson, "The New Testament's Anti-Jewish Slander and the Conventions of Ancient Polemic," JBL 108.3 (1989), 419-441.

${ }^{71}$ Since he specifically rejects this framing of the issues, it would be unfair to include Bibliowicz here. Bibliowicz emphasizes that Hebrews is arguing against Gentile attraction to another form of Christianity, the Jewish form, but, unless we locate this form of Christianity outside Judaism, something that Bibliowicz does not seem to be advocating, there is no substantial difference between this reconstruction and Wilson's.
} 
was mixed. Perhaps some would have regarded it as apostasy (cf. Acts 6:8-8:3; 21:21) or "highly abusive," 72 but this does not necessarily situate Hebrews outside the Judaism of the day, for it was not uncommon for fellow Jews to strongly disagree, and even violently reject each other (e.g. Ps. Sol. 4; 1QS II 4-10; Josephus, J.W. 6:99-111; Ant. 11:340; m. Nidd. 4:1-2; 7:4-5; m. R. Sh. 2:1-2; m. Shebi. 8:10). ${ }^{73}$ As Paula Fredriksen notes:

\begin{abstract}
Intolerance of its own diversity characterizes late Second Temple Judaism, and accounts for much of its sectarian literary production. The intra-group vituperation and intense debate about authority, behaviour, and biblical interpretation that marks canonical and extra-canonical paleo-Christian texts (Paul's letters, the gospels, Barnabas [perhaps], Revelation) are some of the most Jewish things about them. ${ }^{74}$
\end{abstract}

Although she does not specifically mention Hebrews, her consideration of Barnabas suggests that it would be included in a more comprehensive list. The anti-Jewish interpretation of Hebrews then, seems to have been facilitated, at least in part, by an $a$ priori and anachronistic judgment on the nature of Judaism and Christianity at the time of composition, and on Hebrews as firmly rooted in the latter in contradistinction to the former. Anti-Jewish interpretations are almost inevitable from such a standpoint. Recent developments in Jewish Studies and New Testament Studies, however, suggest a more historically credible standpoint for interpreting first-century "Christian" texts, namely, from the perspective of a diverse and complex Second Temple Judaism in which the two ways of Judaism and Christianity had not yet emerged, let alone parted. From this point of view, anti-Jewish interpretations of Hebrews garner less momentum, and cease to be so inevitable.

\title{
The Specificity of the Criticisms
}

Another area of neglect in the anti-Jewish interpretations of Hebrews is the failure to assimilate the specificity of the author's criticisms. Since the time of Chrysostom it has typically been supposed that the author of Hebrews was mounting an argument for the wholesale abrogation of Judaism in favour of Christianity. Aside from the implicit anachronisms in such proposals, discussed above, there is also reason to question the alleged extent of the author's polemic. Although Chrysostom's criticisms of the Levitical priesthood and sacrifices are somewhat starker than those found in Hebrews, at least such criticisms are found in Hebrews $(7: 11-19 ; 10: 1-10)$. When Chrysostom universalizes this note of criticism, however, to include Jewish laws and rituals that are not criticized in Hebrews, we have reason to question his interpretation.

In Hebrews 7:13-17, for example, the author addresses the problem posed to Jesus' priesthood by his descent from Judah, for "with respect to that tribe Moses said nothing about priests" (7:14). Therefore, the author of Hebrews notes, Jesus became a priest "not

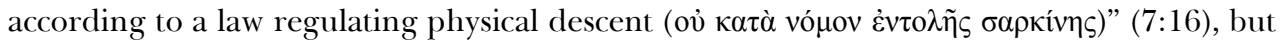

\footnotetext{
${ }_{72}$ Bibliowicz, Jews and Gentiles, 134.

${ }^{73}$ See Johnson, "The New Testament's Anti-Jewish Slander," 434-441.

${ }^{74}$ P. Fredriksen, "What 'Parting of the Ways?"” in The Ways that Never Parted, eds. Becker and Reed, 62 n. 86.
} 
on the basis of his resurrection and heavenly ascent, which situates him in the priesthood of Melchizedek. ${ }^{75}$ In the hands of Chrysostom, however, the scope of Hebrews 7:16 is considerably enlarged. According to Chrysostom, when the author of Hebrews said "not

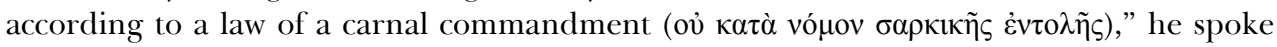
well, for the law was really no law, and was only concerned with carnal things such as circumcision, purification, Sabbath observance etc. ${ }^{76}$

Two things stand out from Chrysostom's use of this text. First, he uses a partial

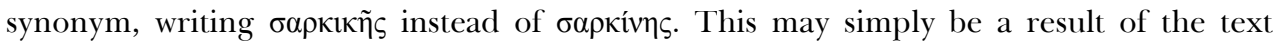
before him since there is some marginal manuscript support for баркıкп̃ , but the use of

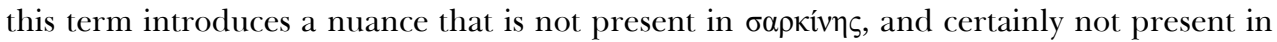

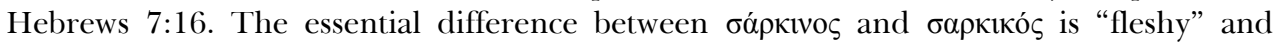
"fleshly"; the former denotes that which pertains to the flesh or physical body, whereas the latter denotes that which is characterized by the flesh, and is open to more derogatory connotations. The difference is subtle, and not always observed, but in this instance it is appropriately represented in translation by using the terms "physical" and "carnal." Second, the author of Hebrews defines the law in question as a specific commandment concerning the hereditary determination of priests, and, out of respect for that law, develops the notion of a heavenly priesthood in the order of Melchizedek. Chrysostom, on the other hand, characterizes the law itself as essentially carnal, and includes a whole host of Jewish laws, customs, and rituals that are not mentioned in Hebrews, some of which may even be implicitly endorsed in Hebrews (see below). Chrysostom's interpretation of Hebrews as a comprehensive condemnation of the entire Jewish $\pi$ o $\lambda \iota \tau \varepsilon i ́ \alpha$ is clearer still in his Orations Against the Jews, as we have seen above.

The tendency to universalize the polemic in Hebrews is also present in modern works, as the five studies discussed above illustrate. Bibliowicz, for instance, claims that "Hebrews deploys a mostly self-referential argument about the inferiority of the beliefs and traditions of the descendents of the founding fathers that encompasses all aspects of Jewish life." 77 According to Wilson, the "clear and unambiguous judgment" of Hebrews is that "Judaism is defunct, because it has been surpassed,"78 and both Gager and Ruether speak in terms of the "absolute" abrogation of Judaism in Hebrews. ${ }^{79}$ The clumsy way in which this assessment is often asserted can be seen by Gager's and Ruether's use of Hebrews 10:1. According to Ruether, this verse teaches that the "Torah is only a shadow of the good things to come, not the true form of these things, " 80 whereas Gager seems to take it as a reference to "the old covenant, which was never more than a shadow of the good things to come." ${ }^{81}$ However, the law (not the covenant) is indeed the subject of the sentence, but it is described as having ( $\check{\chi} \chi \omega v)$ a shadow (not being a shadow) of the good things to come, and, as the immediate context makes plain, that shadow is the Levitical cultus. ${ }^{82}$ Indeed, one

\footnotetext{
${ }^{75}$ See D. M. Moffitt, Atonement and the Logic of Resurrection in the Epistle to the Hebrews (NovTSup 141; Leiden: Brill, 2011); J. A. Barnard, The Mysticism of Hebrews: Exploring the Role of Jewish Apocalyptic Mysticism in the Epistle to the Hebrews (WUNT II/331; Tübingen: Mohr Siebeck, 2012).

${ }^{76}$ The relevant passage is given above.

77 Bibliowicz, Jews and Gentiles, 135 (emphasis mine).

78 Wilson, Related Strangers, 122-123 (emphasis mine).

${ }^{79}$ Gager, Origins, 181; Ruether, Faith and Fratricide, 107.

${ }^{80}$ Ruether, Faith and Fratricide, 108.

${ }^{81}$ Gager, Origins, 183.

${ }^{82}$ See B. C. Joslin, Hebrews, Christ and the Law: The Theology of the Mosaic Law in Hebrews 7:1-10:18 (Milton Keynes, UK: Paternoster, 2008), 244-254.
} 
might argue that the entirety of the author's polemic is in fact focussed on the Levitical cultus.

In a recent article by Richard Hays this is precisely what he claims. Contrary to his earlier opinion of Hebrews as "relentlessly supersessionist," Hays declares that "such assessments are too often grounded in a superficial reading of the evidence" and "are not based on any serious exegesis of the text itself." ${ }^{33}$ Instead, Hay's proposes that the teaching of Hebrews is better described as a form of "Jewish sectarian New Covenantalism." In the course of his analysis, Hays concludes that

the letter to the Hebrews nowhere speaks of Jews and Gentiles, nowhere gives evidence of controversies over circumcision or food laws, criticizes nothing in the Mosaic Torah except for the Levitical sacrificial cult, and contains no polemic against Jews or Jewish leaders ... When the old covenant is contrasted unfavourably to the new, the specific deficiency of the old is described exclusively in terms of the ancient sacrificial cult as a means of atonement for sins. ${ }^{84}$

The specificity of the author's criticisms, and concomitant absence of a comprehensive supersessionism, is a point well made, and one with which his respondents, Oskar Skarsaune and Mark Nanos, concur. ${ }^{85}$ Nanos pushes the point further still, noting that even this specific criticism is tempered by the author's attribution of the Levitical cultus to God's design (e.g. Heb 8:5). ${ }^{86}$

Of the five studies discussed in the previous section, Lloyd Kim's is by far the most attentive to the specificity of the author's criticisms, but, in addition to the Levitical cultus, he maintains that the author's polemic also encompasses the Mosaic Law and Covenant. Like other aspects of Kim's study, however, this may also need to be nuanced a little more carefully. First, in the process of examining priesthood (Heb 7:11-19) and sacrifice (Heb 10:8-9), Kim offers some passing comments about the law. ${ }^{87}$ Although he accepts that the references to the law are specifically dealing with the Levitical cultus, Kim notes that it may be a modern imposition to divide the ethical elements of the law from the cultic, and that by criticizing a part of the law, the author may be implicating the whole law. While it is true that Hebrews provides no basis for a distinction between ethical and cultic parts of the law, this is quite different from acknowledging the specificity of the author's criticisms. The former is imposed upon the text, whereas the latter emerges from the text, as Kim admits. Although Kim's speculation about the possible implications of the author's comments may be valid, it remains inconclusive, and is no basis for including the law among the targets of the author's polemic.

Second, Kim devotes an entire chapter to the significance of the Mosaic covenant in Second Temple Judaism, and the socio-rhetorical function of Hebrews 8:1-13 in the light of it. Kim's argument for the widespread importance of the Mosaic covenant in ancient Jewish society goes without saying, so when the author of Hebrews describes it as

\footnotetext{
${ }^{83}$ R. B. Hays, “'Here We Have No Lasting City': New Covenantalism in Hebrews,” in Epistle to the Hebrews, eds. R. Bauckham et al., 151.

${ }^{84}$ Ibid., 154, 165; cf. Anderson, "Who Are the Heirs," 255-277.

${ }^{85}$ O. Skarsaune, "Does the Letter to the Hebrews Articulate a Supersessionist Theology? A Response to Richard Hays," in Epistle to the Hebrews, eds. R. Bauckham et al., 175, 180; Nanos, "New or Renewed," 184, 186-187.

${ }_{86}$ Ibid.

${ }^{87}$ Kim, Polemic, 87-88, 186-187.
} 
"obsolete," "growing old," and "close to nullification" (8:13), 88 it is fair to assert that it would have "sounded alarming to Jewish ears," and been "devastating" to a Jewish community. ${ }^{89}$ It is significant, however, that Kim does not examine Hebrews 9, which limits this covenant language to the Levitical cultus. Taken in isolation, Hebrews 8:13 certainly sounds like the radically discontinuous statement that most take it to be, but this needs to be nuanced in light of the author's focus upon the "cultic regulations" of the first covenant (9:1-10), and the fact that the new covenant is enacted by Jesus' atoning sacrifice (9:11-17), and mediated on the basis of his heavenly high priesthood (7:20-22; 8:1-6).

Thus, according to Hebrews, that which is "old" or "obsolete" in the Mosaic covenant is the earthly Levitical cultus, something that may already have been inferred from the destruction of the Temple, ${ }^{90}$ and that which is "new" in the new covenant is the atoning sacrifice and high priesthood of Jesus in the heavenly Melchizedekian cultus. The use of new covenant language is effective in driving home the significance of the sectarian innovations, but, in view of the author's specific concern with the Levitical cultus, it is inappropriate to construe the new covenant in Hebrews as a replacement of God's covenant with Israel. Despite the radical nature of the innovations, the new covenant is still understood in terms of God's covenant with Israel. Like the Mosaic covenant (e.g. Ex. 6:3), the author's new covenant ideology does indeed envisage a change in God's relationship with his people, but, also like the Mosaic covenant, it is a continuation and development of that same basic relationship. Nanos may be closer to the mark, therefore, when he describes the author's presentation as "Renewed Covenantalism," and suggests that the covenant is "continued but augmented to be made effective in a new way or to a new degree." 91 The use of new covenant language to conceptualize an eschatological Jewish sect in continuity with the ancestral covenant is illustrated by the Damascus Document and Dead Sea Scrolls (e.g. CD-A VIII:16-21; 1QpHab II), and, in this respect, is perhaps more comparable to the new covenant language in Hebrews than Kim allows. ${ }^{92}$

\section{The Eschatology of the Innovations}

The author of Hebrews clearly believed that a definitive atonement for sins had been made once and for all, and that the eschatological age had begun (e.g. Heb 1:2-3; 9:26). Moreover, in contrast to at least one school of ancient Jewish thought (e.g. Deut. 30:12; Ps. 115:16; 3 Macc. 2:15; Josephus, Ant. 3:181), it is maintained that the heavenly realm, wherein the eschatological innovations are actualized, is presently accessible. This is evident not only from the fact that Jesus is thought to have ascended there (Heb 4:14; 8:1-

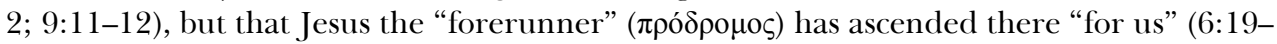
20). The term "forerunner" denotes one who undergoes an experience in advance of others in order to show the way, and suggests that the prospect of heavenly ascent is presently available for all the faithful followers of Jesus. This seems to be confirmed by the author's exhortations to pursue the heavenly sanctuary and throne of God $(4: 16 ; 10: 19$

\footnotetext{
${ }^{88}$ Kim's translation (ibid., 137).

89 Ibid., 122.

${ }^{90}$ Cf. Eisenbaum, "Locating," 226.

${ }_{91}$ Nanos, "New or Renewed," 185 (emphasis his).

${ }^{92} \mathrm{Kim}$, Polemic, 110-117.
} 
22), and the assertion that the addressees are those who have come to the heavenly Jerusalem and communed with angels (12:22-24), all of which is reminiscent of ancient Jewish mysticism. ${ }^{93}$ This "realized eschatology" is a major emphasis of Hebrews and undergirds much of the author's innovations and criticisms. Although it pushes Hebrews towards the edges of ancient Judaism, the analogous Jewish apocalyptic and mystical traditions suggest that it need not breach those boundaries (e.g. 1 Enoch, 4Q400-407), a consideration that is often underappreciated in the anti-Jewish interpretations of Hebrews. ${ }^{94}$ In this section, however, I shall highlight the impact that Hebrews' futuristic eschatology has on anti-Jewish interpretations.

In addition to the strong theme of realized eschatology in Hebrews, there is also clear evidence of a futuristic eschatology, references to expectations that are not yet fulfilled. For example, despite the present mystical entry into the heavenly Jerusalem (12:22-24), the people behind Hebrews are looking forward to "the city to come" (13:14); despite visions of their high priest resting in glory $(1: 3-13$; cf. $2: 9 ; 12: 24)$, this is qualified as a revelation of "the world to come" (2:5). When the author composed his message, the faithful followers of Jesus were "eagerly awaiting" his second coming and salvation (9:28), and Jesus was understood to be waiting for his enemies to become a footstool for his feet (10:13). Thus, although the author stresses that which is realized, like other New Testament documents, we observe an "eschatological ambiguity" in Hebrews in which the eschatological age is partly fulfilled yet incomplete. ${ }^{95}$ Although the eschatological age had begun, and the world to come could be accessed, mystically, in heaven, the author of Hebrews was still waiting for that long-expected "Day of the Lord" of traditional Jewish eschatology.

As Hays notes, this "open-ended eschatology" places the people behind Hebrews within Israel's "ongoing and unfinished story," and tempers the supersessionist interpretations by recognizing the "provisional character" of their new understanding. ${ }^{96}$ Similarly, Nanos observes that the very existence of this "word of exhortation" (13:22) suggests that the new covenant has not yet been experienced.

Those who experience Jer. 31 do not need to have their "faculties trained by practice to distinguish good from evil" (Heb. 5:14). They do not need to be taught; this kind of letter does not need to be written to them; they just know what needs to be known ... Exhortation will itself be finished when that day arrives, according to the text of Jeremiah - and Hebrews. So it cannot have arrived, one might logically deduce. ${ }^{97}$

\footnotetext{
${ }_{93}$ See Barnard, Mysticism of Hebrews; J. A. Barnard, "Ronald Williamson and the background of Hebrews," The Expository Times 124.10 (2013), 469-479; S. D. Mackie, "Ancient Jewish Mystical Motifs in Hebrews' Theology of Access and Entry Exhortations," NTS 58 (2012), 88-104; S. D. Mackie, "Heavenly Sanctuary Mysticism in the Epistle to the Hebrews," JTS 62 (2011), 77-117; C. Rowland and C. R. A. Morray-Jones, The Mystery of God: Early Jewish Mysticism and the New Testament (CRINT 12; Leiden: Brill, 2009).

${ }_{94}$ For the suggestion that Hebrews bears witness to an early "Christian" expression of Jewish apocalyptic mysticism, see Barnard, The Mysticism of Hebrews.

${ }_{95}^{5}$ See S. D. Mackie, Eschatology and Exhortation in the Epistle to the Hebrews (WUNT II/223; Tübingen: Mohr Siebeck, 2007).

${ }_{96}$ Hays, "New Covenantalism," 162-163.

${ }_{97}$ Nanos "New or Renewed," 186-187.
} 
Since the author of Hebrews believes that the new covenant has arrived, Nanos finds his argument illogical and incoherent, ${ }^{98}$ but perhaps this "incoherence" may be explained with reference to the eschatological ambiguity of Hebrews. It would seem that the vision of the new covenant as described by Jeremiah and quoted in Heb 8:8-12 was only partially realized at the time of writing, and primarily pertained to the atoning effects of Jesus' sacrificial offering. As we have noted above, the principal import of the covenant language concerns priestly sacrifices, a focus that is reiterated when the author repeats what he regards as the most significant portion of Jeremiah's "new covenant" text.

For by a single offering he [Jesus] has completed forever those who are being sanctified. The holy spirit also testifies to us, for after he said "This is the covenant that I will make with them after those days, says the Lord, I will put my laws upon their hearts, and inscribe them upon their mind" [Jer. 31:33; Heb 8:10], he says, "their sins and lawless deeds I shall remember no more [Jer. 31:34; Heb 8:12]." When there is a remission of these things then, there is no longer an offering for sins. (Heb 10:14-18)

As both the immediate literary context, and the way in which this quotation is introduced, show, the author's primary concern is with the remission of sins. The first part of the quotation not only serves to locate the text, but also to specifically highlight the atoning features of the new covenant. In other words, the realized aspect of the new covenant is the complete remission of sins, but the time when Torah is written on the heart, and everyone knows the Lord without being taught, is not yet experienced, but rather, anticipated. It appears to be anticipated soon, and when it arrives the author expects that

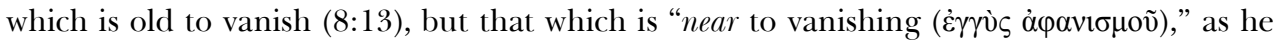
puts it, has not yet vanished. For Hebrews then, although the former covenant is in the process of being absorbed, continued, and developed in the latter, both covenants are operational and neither covenant is fully functional.

It is far too simplistic, therefore, to characterize the new covenant of Hebrews in terms of a complete and definitive "voiding" and "replacing" of the Mosaic covenant, or even as a "fulfilment," as many do. Bibliowicz, for example, in his comments on Hebrews 8, writes that Jeremiah 31

is subverted to support the advent of a new covenant with non-Israelites (8:8), the collapse of the "old" (8:9), and the superiority of the new $(8: 10-11) \ldots$ There is no room or reason for the first covenant to continue, once the second has been established. The emergence of the second or new covenant renders the first old, null, and void. ${ }^{99}$

Aside from his assumption of an exclusively Gentile context, leading to the remarkable assertion that $H e b$ 8:8 refers to non-Israelites, this understanding of the new covenant fails to assimilate the specificity and eschatology of the author's comments. The new covenant is indeed regarded as superior (e.g. 8:6), but, as we have seen, it is also regarded as

${ }_{98}$ Ibid., 187; cf. A. J. M. Wedderburn, "Sawing Off the Branches: Theologizing Dangerously Ad Hebraeos," JTS 56 (2005), 393-414.

${ }^{99}$ Bibliowicz, Jews and Gentiles, 124-125; cf. Wilson, Related Strangers, 122: "if the old covenant is recognized as foreshadowing the new, it is only a shadow or sketch, which is then comprehensively overtaken (8:5)" (emphasis his). 
incomplete, and its present "updating" effect is far from comprehensive. According to Hebrews, the present functionality of the new covenant pertains to the messianic high priesthood and atoning sacrifice of Jesus, thereby bringing about a change - or solution, if Hebrews is responding to the absence of the Levitical cultus - with respect to priestly sacrifices. In other respects, there is plenty of room for the former covenantal arrangements and regulations to continue. Although the author expected further changes to take place, presumably when Jesus returns $(9: 28 ; 10: 37-38)$, there is no basis for denying that in the meantime God's covenant with Israel continued in the age-old way. Without explicit evidence to the contrary, and read within the parameters of late Second Temple Judaism, there is every reason to suppose that these "descendents of Abraham" (2:16) belonging to the "house of Moses" (3:5-6) were expected to maintain their covenantal faithfulness in accordance with the ancestral customs.

\section{The Place of Jewish Practices}

Whatever their conclusions regarding the anti-Jewish character of Hebrews, most scholars acknowledge at least some continuity between Hebrews and the Judaism of the day. The author's use of the Jewish Scriptures, for instance, is one such area in which a substantial continuity is widely recognized. ${ }^{100}$ The world of Hebrews is very much a scriptural world, ${ }^{101}$ and the numerous and extended quotations, expositions, and exegetical methods, securely situates it in the Jewish world. ${ }^{102}$ What is almost completely overlooked, however, is the place of Jewish practices in Hebrews. Hebrews does not discuss circumcision, Sabbath observance, or dietary laws, for example, the three practices that regularly characterize Jews in the ancient world. ${ }^{103}$ The silence of Hebrews on these matters partly explains why they are overlooked in the secondary literature, but it does not justify the supposition that they were not important or had been rejected. If the people behind Hebrews are Jewish believers in Jesus, as seems most likely, then this silence can just as easily be understood as an acceptance of these basic Jewish practices. Although there is no unambiguous mention of circumcision, Sabbath observance, or dietary laws in Hebrews, there appears to be an acceptance of Jewish purification rituals (6:2; 10:22), 104 and, although it is usually understood as a rejection of Jewish dietary practices, ${ }^{105}$ the reference to "foods" in Heb 13:9 could easily be a warning about the culinary habits of Gentiles (cf. 1 Macc. 1:62-63; Acts 15:29; 21:25; 1 Cor. 8:1-13; 10:14-33; Rev. 2:20), thereby indirectly endorsing a traditional Jewish diet. These possibilities are rarely, if ever, entertained in the anti-Jewish interpretations of Hebrews, but they at least serve to complicate, if not overturn, much of what is claimed in such portrayals.

\footnotetext{
${ }^{100}$ See G. Guthrie, “Hebrews' Use of the Old Testament: Recent Trends in Research,” CBR 1.2 (2003), 271-294.

${ }^{101}$ L. T. Johnson, "The Scriptural World of Hebrews," Int 57 (2003), 237-250.

${ }^{102}$ E. Tönges, "The Epistle to the Hebrews as a 'Jesus Midrash," in Hebrews, ed. Gelardini, 89-105; S. E. Docherty, The Use of the Old Testament in Hebrews: A Case Study in Early Jewish Bible Interpretation (WUNT II/260; Tübingen: Mohr Siebeck, 2009).

${ }_{103}$ See, for instance, P. Schäfer, Judeophobia: Attitudes toward the Jews in the Ancient World (Cambridge, Massachusetts; London, England: Harvard University Press, 1997).

104 See Barnard, Mysticism of Hebrews, 194-202.

${ }^{105}$ E.g. Wilson, Related Strangers, 116-17; Bibliowicz, Jews, 118-119.
} 
One further Jewish practice that might be registered in Hebrews is that of synagogue attendance, to which we now turn. In Heb 10:24-25 the author urges his brothers to promote love and good deeds which is not done by neglecting their $\dot{\varepsilon} \pi \sigma v v \alpha \gamma \omega \gamma \eta$ but by

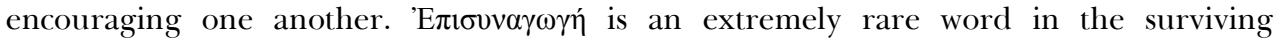
literature. The term is used in a second-century BCE stele from the island of Symi to denote a "collection" or "sum" of money. 106 A similar usage is registered by Claudius Ptolemy, the second-century CE astronomer and mathematician, to denote a "calculation," that is, a "collection" or "sum" of numbers (Tetrabiblos 1:20). Somewhat closer to its usage in Hebrews are the two other biblical references where it denotes an eschatological "gathering" of God's people (2 Macc. 2:7; 2 Thess. 2:1; cf. Eusebius, Hist. eccl. 7.24.5). Even though we have so few examples of this term, its basic sense is clear; it denotes some kind of "gathering together" or "assembly," and is essentially synonymous with $\sigma 0 v \alpha \gamma \omega \gamma \eta$. ${ }^{107}$

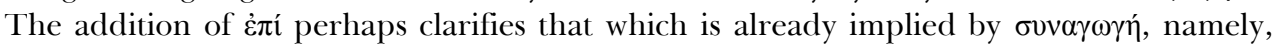
assembly at a particular location. The term finds a partial antonym in the Johannine

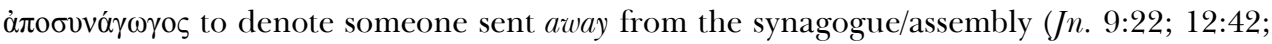
16:2).

According to our earliest text of Hebrews ( $\mathrm{P}^{46}$ c. $200 \mathrm{CE}$ ), the prepositional prefix is dotted for deletion, an action that was apparently carried out by the original scribe. ${ }^{108}$ This

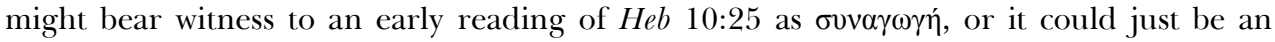
example of the scribe's apparent preference for simple words over compound words. 109

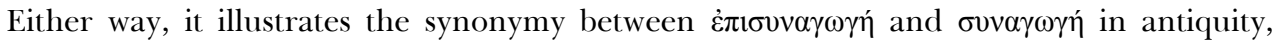

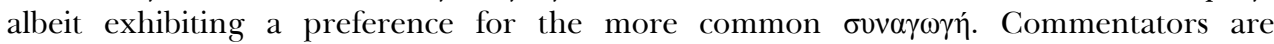
generally content to explain its use in Hebrews with reference to 2 Macc. 2:7 and 2 Thess. 2:1, noting the common eschatological thread between them. This overlooks the difference

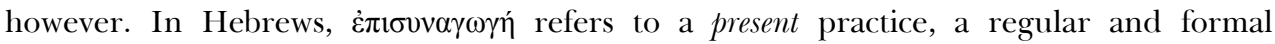
gathering that provides an opportunity for mutual edification, the importance of which is highlighted with respect to the nearness of the Day of the Lord. In 2 Maccabees and 2

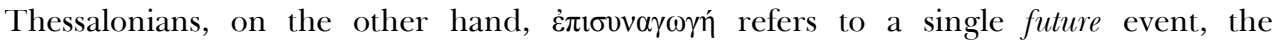
eschatological ingathering that shall take place on the Day of the Lord. Thus, the use of this rare term in Hebrews is not entirely comparable to other extant examples, but its similarity to its synonym $\sigma u v \alpha \gamma \omega \gamma \eta$, on the other hand, is striking, and it might provide another reference to an ancient synagogue service.

The recent surge in specialist synagogue studies has already served to dismantle longheld misconceptions about the origins, nature, and development of the synagogue, and, with the help of new archaeological discoveries and the use of new methods and perspectives, is facilitating a robust basis for a new consensus formation. ${ }^{110}$ Perhaps one of the most famous discoveries pertaining to the ancient synagogue is the Theodotos

${ }_{106}$ A. Deissmann, Light from the Ancient East, trans. L. R. M. Strachan (London: Hodder and Stoughton, 1927), 103.

${ }^{107}$ Ibid.

${ }_{108}$ So J. R. Royse, Scribal Habits in Early Greek New Testament Papyri (Leiden: Brill, 2008), 234, 318 n. 670.

109 Ibid., 326.

${ }^{110}$ See, for example, S. Fine, This Holy Place: On the Sanctity of the Synagogues during the Greco-Roman Period (Notre Dame: University of Notre Dame Press, 1997); A. Runesson, The Origins of the Synagogue: A Socio-Historical Study (Stockholm: Almqvist \& Wiksell International, 2001); L. I. Levine, The Ancient Synagogue: The First Thousand Years (rev. ed., New Haven, Connecticut: Yale University Press, 2005); A. Runesson, D. D. Binder, and B. Olsson, The Ancient Synagogue from its Origins to 200 C.E. A Sourcebook (Leiden: Brill, 2008). 
inscription, discovered in Jerusalem in 1913 by the French archaeologist Raimund Weill. Securely dated to the First Century CE, it provides a valuable snapshot of a Second Temple period synagogue in the Land of Israel.

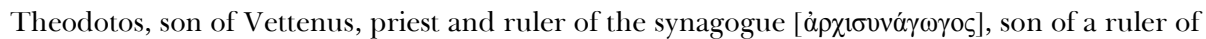

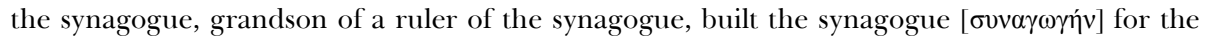
reading of the law and the teaching of the commandments, and also the guest chamber and the upper rooms and the ritual pools of water for accommodating those needing them from abroad, which his fathers, the elders and Simonides founded. ${ }^{111}$

Allowing for regional variations and developments, this inscription touches on a number of common features of ancient synagogues. They typically operated with some kind of leadership that was not dominated by the Pharisees; they were built for Torah-centred liturgical purposes but also accommodated various community activities, as indicated by the reference to the guest chamber and upper rooms, and provided some kind of means for ritual purification. ${ }^{112}$

The community functions of ancient synagogues are diverse. Among other things they could be used as lodgings (e.g. Josephus, Ant. 14:374), archives (e.g. Josephus, J.W. 2:291), treasuries (e.g. Josephus, Ant. 16:164; Mt. 6:2), and courts (Josephus, Ant. 14:235; Mk. 13:9; Acts 22:19; m. Makk. 3:12). Among the liturgical activities, the public reading of the Torah, particularly on the Sabbath, is "explicit in almost every type of source from the Second Temple period in Judea and in the Diaspora - in cities and in villages." 113 Acts is probably just about right, therefore, when James declares that "from ancient times, and in every city, Moses is proclaimed, for he is read aloud every Sabbath in the synagogues

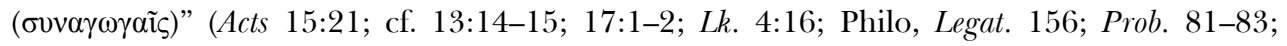
Josephus, $A g$. Ap. 2:175; J.W. 2:289-92; m. Yom. 7:1).

In addition to the reading of the Torah, we may be fairly confident that the Prophets were also often included (e.g. Lk. 4:17; Acts 13:15, 27; m. Meg. 4:1-5; t. Meg. 3:1-18), and that serious attention was given to teaching, expounding, and applying these sacred texts and traditions (e.g. Philo, Somn. 2:127; Legat. 156; Hypoth. 7:11-14; Josephus, Ag. Ap. 2:175; Lk. 13:10; Jn. 6:59; Acts 13:15, 42; 4Q251 1:5). According to Levine, "the evidence shows that by the first century, a weekly ceremony featuring communal reading and study of sacred texts was a universal Jewish practice." 114 With all due respect to the variety within this unity, and the likelihood that there were also other activities associated with the ancient synagogue, such as prayer and praise, ${ }^{115}$ for example, it is beyond all reasonable doubt that synagogue attendance was one of the distinguishing characteristics of Jews living in the First Century CE. Therefore, there is every reason to suppose that Jesus-

\footnotetext{
${ }^{111}$ Runesson et al., Ancient Synagogue, 53.

${ }^{112}$ See L. I. Levine, “'Common Judaism': The Contribution of the Ancient Synagogue," in Common Judaism, eds. McCready and Reinhartz, 27-46.

${ }^{113}$ Ibid., 41; cf. L. H. Schiffman, "The Early History of the Public Reading of the Torah," in Jews, Christians, and Polytheists in the Ancient Synagogue, ed. S. Fine (London: Routledge, 1999), 44-56.

${ }^{114}$ L. I. Levine, "Common Judaism," 42; cf. E. P. Sanders, "Common Judaism and the Synagogue in the First Century," in Jews, ed. Fine, 1-17.

${ }^{115}$ The notion that the synagogue was a place of Sabbath worship prior to the Third Century C. E. has been challenged recently (e.g. H. A. McKay, Sabbath and Synagogue: The Question of Sabbath Worship in Ancient Judaism [Leiden: Brill, 1994]). For a rebuttal, see P. W. van der Horst, "Was the Synagogue a Place of Sabbath Worship Before 70 CE?," in Jews, ed. Fine, 18-43.
} 
believing Jews would have participated in this "universal Jewish practice," as the book of Acts suggests (e.g. 6:9;9:20;13:14;16:13, 16; 22:19; 26:11), and to picture the faithful Jesus-believing Jews behind Hebrews as regular synagogue attendees, similar to those addressed in James (see Jas. 2:2). ${ }^{116}$ Although some were neglecting this practice, and had perhaps "parted ways," the direct recipients of Hebrews were not, at least not yet, and the

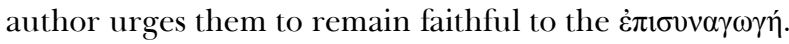

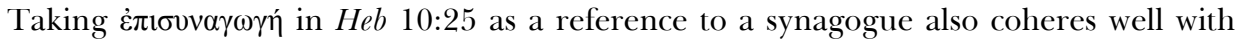
the activities that the author associates with it, namely, the promotion of love and good deeds, and mutual encouragement (10:24-25). The term used to denote "encouragement" $(\pi \alpha \rho \alpha \kappa \alpha \lambda \tilde{\omega})$ is the same term that is used to describe the speech that is Hebrews, a $\lambda$ ó $\gamma \circ \varsigma \tau \tilde{\eta} \varsigma$ $\pi \alpha \rho \alpha \kappa \lambda \eta \dot{\sigma \varepsilon \omega \varsigma}$, "message of encouragement/exhortation" (13:22), which provides an insight

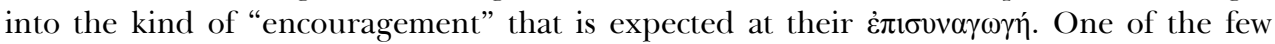
areas in which scholarship on Hebrews has approached something of a consensus is with regard to genre. Although it concludes like an epistle, and was written down and sent like an epistle, it lacks certain epistolary conventions, such as an address, for example. ${ }^{117}$ Given the oral (e.g. 2:5; 8:1; 11:32), exegetical (e.g. 3:7-4:13; 8:7-10:18), and hortatory (e.g. 2:14 ; 4:14-16; 10:19-39) character of Hebrews, and in view of the author's own description of his work as a "message of encouragement" ( $\lambda$ ó $0 \varsigma \tau \tilde{\eta} \varsigma \pi \alpha \rho \alpha \kappa \lambda \eta \dot{\sigma} \sigma \omega \varsigma \varsigma$ ), a phrase used in Acts 13:15 to denote a synagogue homily (cf. 2 Macc. 15:11), Hebrews is typically classified as an example of an ancient Hellenistic Jewish/Christian sermon or homily. ${ }^{118}$ The account of Paul and his companions attending the synagogue in Pisidian Antioch gives us an idea of the kind of situation in which Hebrews could have been read (Acts 13:13-52). After the readings from the Torah and the Prophets, the synagogue leaders invite Paul and his

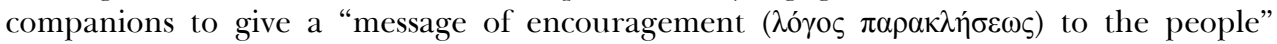
(13:13-15; cf. Rom. 16:4), and it is at a juncture such as this that Hebrews was probably first intended. It has even been calculated that Hebrews was a synagogue homily specifically intended for the Ninth of Av, but this rests upon a particular interpretation of practices that are only attested in some rabbinic sources from a later period. 119 Nevertheless, in general terms, the liturgical activities in the synagogue on the Sabbath make excellent sense as an occasion for the delivery of this "exhortative speech." When the author of Hebrews speaks about encouraging/exhorting one another in relation to the $\dot{\varepsilon} \pi \iota \sigma v v \alpha \gamma \omega \gamma \eta \dot{n}(10: 25)$, therefore, this could be his way of characterizing the various readings, expositions, and discussions of sacred texts that take place every Sabbath in the synagogue (e.g. Philo, Hypoth. 7:11-14; Josephus, Ag. Ap. 2:175).

Similarly, the promotion of "love and good deeds" (Heb 10:24) also coheres well with the liturgical activities of ancient synagogues. In his treatise Every Good Man is Free, for example, Philo points to the Essenes as men of exemplary character (Prob. 75-91). Among

\footnotetext{
${ }_{116}$ On the reference in James, see D. C. Allison Jr., James: A Critical and Exegetical Commentary (London; New York: Bloomsbury T\&T Clark, 2013), 385-388.

${ }^{117}$ See Deissmann, Light, 146-251 (243-244 on Hebrews); H. W. Attridge, Hebrews (Hermeneia; Philadelphia: Fortress Press, 1989), 13-14.

${ }_{118}$ See L. Wills, "The Form of the Sermon in Hellenistic Judaism and Early Christianity," HTR 77:3-4 (1984), 277 299; C. Clifton Black II, "The Rhetorical Form of the Hellenistic Jewish and Early Christian Sermon," HTR 81:1 (1988), 1-18; H. Attridge, "Paraenesis in a Homily," Semeia 50 (1990), 211-226; H.-F. Weiss, Der Brief an die Hebräer (KEK 13; Göttingen: Vandenhoeck \& Ruprecht, 1991), 35-41; Tönges, "Epistle to the Hebrews," 89-105.

119 G. Gelardini, "Hebrews, An Ancient Synagogue Homily for Tisha be-Av: its Function, its Basis, its Theological Interpretation," in Hebrews, ed. Gelardini, 107-127; G. Gelardini, "Verhärtet eure Herzen nicht": Der Hebräer, eine Synagogenhomilie zu Tischa be-Aw (Leiden: Brill, 2007).
} 
other things, he refers to their synagogue activities, noting that they assemble on the Sabbath and listen carefully to the sacred books being read and expounded (81-82), and as a result,

They are trained in godliness, holiness, and righteousness, as well as practical and civic matters, acquiring understanding of things that are truly good, or bad, or neutral, and learning how to choose what they ought and flee from its opposite, taking as their defining standards the following three principles: love of God, love of virtue, and love of humanity. (Prob. 83; cf. Spec. 2:62-63; Josephus, Ant. 16:42-43)

By contrast, the author of Hebrews registers a complaint with his addressees, noting some "laziness" with respect to listening, and that although they ought to be teachers, they remain unskilled in righteousness, and untrained in their ability to distinguish between good and bad (Heb 5:11-14). One of the solutions to such immaturity is to pay attention to the provocation of love and good deeds, an activity that Philo and others associate with the

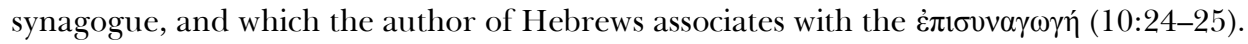

It may also be significant that within the same sentence the author presupposes the

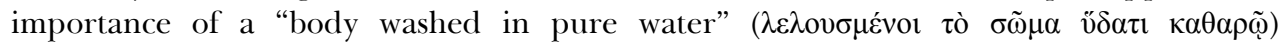
$(10: 22),{ }^{120}$ which is probably a reference to the regular Jewish practice of ritual purification. ${ }^{121}$ If so, then this may be a further indication that the author's reference to

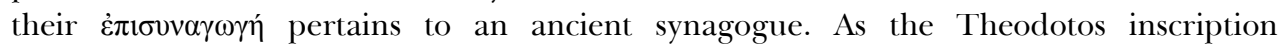
illustrates, ancient synagogues were typically built with water facilities in close proximity; if there was no river (Acts 16:13), or sea (Josephus, Ant. 14:258) nearby then ritual immersion baths were constructed. ${ }^{122}$ This might indicate that Jews purified themselves before entering synagogues or it could simply be convenient, indicating that Jews regularly purified themselves, and regularly attended synagogue, without necessarily suggesting any connection between the two. According to Susan Haber's careful analysis of the archaeological, epigraphic, and literary evidence, the former explanation may be applied to Diaspora Jews, who probably performed ritual ablutions such as hand washing and sprinkling before entering the synagogue. The latter explanation may be applied to Judeans, who regularly immersed themselves in order to maintain ritual purity, although, with the possible exception of Qumran, ${ }^{123}$ probably not for the specific purpose of entering the synagogue. ${ }^{124}$ In any case, two things seem clear, that "Jews purified themselves so that they could draw near to that which was holy," and that "it seems probable that the early synagogue in the Diaspora and in the land of Israel was regarded, at least to some extent, as a sacred realm." ${ }^{25}$ The comment in Heb 10:22, therefore, could also be understood with reference to the synagogue, illustrating the close connection between purifying water

${ }^{120}$ Cf. Lev. 14:9; 15:11, 13, 16, 21, 27; 16:4, 24, 26, 28; 22:6; Num. 5:17; 19:7-8; Deut. 23:12; 11Q19 45:1516; Philo, Deus 8; Spec. 1:261; Josephus, J.W. 2:129; Ant. 12:145; 14:285; Mk. 7:4; Heb 6:2; Acts 21:20-26.

121 See Barnard, Mysticism of Hebrews, 194-202.

122 See S. Haber, "Common Judaism, Common Synagogue? Purity, Holiness, and Sacred Space at the Turn of the Common Era," in Common Judaism, eds. McCready and Reinhartz, 63-77; R. Reich, "Miqwa'ot (Jewish Ritual Immersion Baths) in Eretz-Israel in the Second Temple and the Mishnah and Talmud Periods" (Ph.D dissertation, Hebrew University of Jerusalem, 1990) [Hebrew].

${ }^{123}$ See J. Magness, The Archaeology of Qumran and the Dead Sea Scrolls (Grand Rapids, Michigan; Cambridge: Eerdmans, 2002), 105-162; H. K. Harrington, The Purity Texts (London; New York: T\&T Clark, 2004).

${ }^{124}$ Haber, "Common Judaism," 63-77.

${ }^{125}$ Ibid., 65, 76 . 
facilities and ancient synagogues (cf. CD-A 11:21-22; Philo, Deus 8; Decal. 45; Josephus, $J . W .2: 129)$. Thus, just as many Jews in the late Second Temple period associate ritual purification, training in godliness, and scripturally-based education and exhortation, with the synagogue assemblies, so it would seem does the author of Hebrews, although he calls

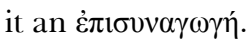

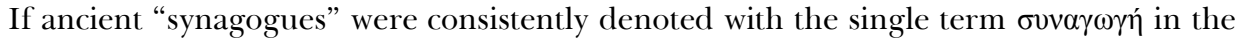

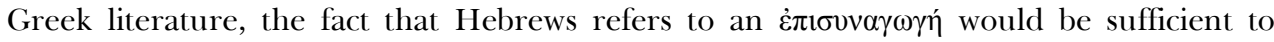
suggest the kind of distinction that is typically taken for granted in the secondary literature. However, what is referred to in English as a "synagogue" went under a number

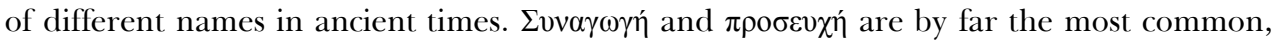

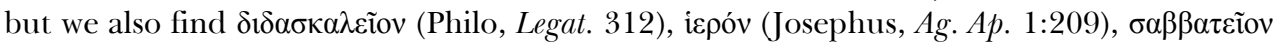

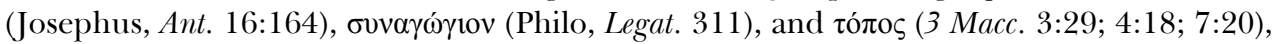
for example. In view of this numerous and diverse terminology for denoting "synagogues"

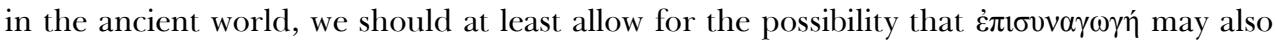
have been used in this way. Given that its use in $\mathrm{Heb}$ 10:25 is not fully comparable with other extant uses of this term, but bears a striking resonance with the ancient ideas about synagogues, perhaps "synagogue" was within its semantic range for a short while, and $\mathrm{Heb}$ 10:25 is our sole surviving example? If so, then, given that synagogue attendance was closely connected with the observance of the Sabbath, we might also suppose the author's practice and encouragement of Sabbath observance.

\section{Conclusion}

Without wishing to deny the possibility that there may be a limited textual basis for antiJewish interpretations of Hebrews, we have found that even the most qualified and nuanced of these still falls short of assimilating all the evidence to the contrary, and of negotiating the various complicating factors adequately. Many modern interpreters continue to operate within the same interpretative paradigms as Chrysostom. A definite (and anachronistic) line is drawn between "Judaism" and "Christianity," Hebrews is fixed firmly in the latter, and perceived to be arguing strongly against the former, and, more often than not, this argument is construed in terms of a wholesale rejection of Judaism, despite the specificity of the criticisms, and eschatology of the innovations. The elusiveness of the social context of Hebrews does not permit the detailed reconstructions that usually accompany such anti-Jewish interpretations. The sectarian beliefs, mystical experiences, and eschatological expectations that may be inferred from the text of Hebrews do not tell us very much about the circumstances behind the text. As far as we know, the day to day lives of the people behind Hebrews may have looked very similar to that of most ordinary Jews of the day, something that may be confirmed by the author's possible passing references to ritual purification and synagogue attendance. In short, classifications of Hebrews as "antiJewish" are not as straightforward as many have supposed, and, at the very least, we may confidently affirm that Chrysostom was way off the mark. 


\section{ABBREVIATIONS}

BBR: Bulletin for Biblical Research

CBR: Currents in Biblical Research

CRINT: Compendia rerum iudaicarum ad Novum Testamentum

HTR: Harvard Theological Review

Int: Interpretation

JBL: Journal of Biblical Literature

JSNT: Journal for the Study of the New Testament

JSNTSup: Journal for the Study of the New Testament: Supplement Series

JSOT: Journal for the Study of the Old Testament

JTS: Journal of Theological Studies

KEK: Kritisch-exegetischer Kommentar über das Neue Testament

NICNT: New International Commentary on the New Testament

NIGTC: New International Greek Testament Commentary

NovTSup: Novum Testamentum Supplements

NTS: New Testament Studies

WUNT II: Wissenschaftliche Untersuchungen zum Neuen Testament II

\section{BIBLIOGRAPHY}

Alexander, P. "“The Parting of the Ways' from the Perspective of Rabbinic Judaism.” In Jews and Christians: The Parting of the Ways, edited by J. D. G. Dunn, 1-25. Tübingen: J. C. B. Mohr (Paul Siebeck), 1992.

Allison Jr., D. C. James: A Critical and Exegetical Commentary. London; New York: Bloomsbury T\&T Clark, 2013.

Anderson, C. P. "Who are the Heirs of the New Age in the Epistle to the Hebrews." In Apocalyptic and the New Testament: Essays in Honour of J. Louis Martyn, edited by J. Marcus and M. L. Soards, 255-257. JSNTSup 24. Sheffield: JSOT Press, 1989.

Attridge, H. "Paraenesis in a Homily." Semeia 50 (1990): 211-226.

- Hebrews. Hermeneia; Philadelphia: Fortress Press, 1989.

Barnard, J. A. The Mysticism of Hebrews: Exploring the Role of Jewish Apocalyptic Mysticism in the Epistle to the Hebrews. WUNT II/331. Tübingen: Mohr Siebeck, 2012.

—. "Ronald Williamson and the background of Hebrews." The Expository Times 124.10 (2013): 469-479.

Bauckham, R., D. R. Driver, T. A. Hart, and N. MacDonald, eds. The Epistle to the Hebrews and Christian Theology. Grand Rapids, Michigan; Cambridge, UK: Eerdmans, 2009.

Becker, A. H., and A. Y. Reed, eds. The Ways that Never Parted: Jews and Christians in Late Antiquity and the Early Middle Ages. Tübingen: Mohr Siebeck, 2003.

Bibliowicz, A. M. Jews and Gentiles in the Early Jesus Movement: An Unintended Journey. New York: Palgrave Macmillan, 2013.

Boyarin, D. The Jewish Gospels: The Story of the Jewish Christ. New York: New Press, 2012. 
Chester, A. Messiah and Exaltation: Jewish Messianic and Visionary Traditions and New Testament Christology. Tübingen: Mohr Siebeck, 2007.

Clifton Black II, C. "The Rhetorical Form of the Hellenistic Jewish and Early Christian Sermon." HTR 81:1 (1988): 1-18.

Cockerill, G. L. The Epistle to the Hebrews. NICNT. Grand Rapids, Michigan: Eerdmans, 2012.

Davies, A. T., ed. Antisemitism and the Foundations of Christianity. New York: Paulist, 1979.

Deissmann, A. Light from the Ancient East, translated by L. R. M. Strachan. London: Hodder and Stoughton, 1927.

Docherty, S. E. The Use of the Old Testament in Hebrews: A Case Study in Early Jewish Bible Interpretation. WUNT II/260. Tübingen: Mohr Siebeck, 2009.

Dunn, J. D. G. Christology in the Making: A New Testament Inquiry into the Origins of the Doctrine of the Incarnation. 2nd ed., London: SCM Press, 1989.

Eisenbaum, P. "Locating Hebrews within the Literary Landscape of Christian Origins." In Gelardini, Hebrews: Contemporary Methods, 213-237.

Ellingworth, P. The Epistle to the Hebrews. NIGTC. Grand Rapids, Michigan: Eerdmans, 1993.

Fine, S. This Holy Place: On the Sanctity of the Synagogues during the Greco-Roman Period. Notre Dame: University of Notre Dame Press, 1997.

- ed. Jews, Christians, and Polytheists in the Ancient Synagogue. London: Routledge, 1999.

Fredriksen, P. "What 'Parting of the Ways?" In Becker and Reed, The Ways that Never Parted, 35-63.

Gager, J. G. The Origins of Anti-Semitism: Attitudes Toward Judaism in Pagan and Christian Antiquity. Oxford: Oxford University Press, 1983.

Gaston, L. Paul and the Torah. Vancouver: University of British Columbia Press, 1987.

Gelardini, G. "Hebrews, An Ancient Synagogue Homily for Tisha be-Av: its Function, its Basis, its Theological Interpretation.” In Gelardini, Hebrews: Contemporary Methods, 107-127.

ed. Hebrews: Contemporary Methods - New Insights. Leiden; Boston: Brill, 2005.

—_. "Verhärtet eure Herzen nicht": Der Hebräer, eine Synagogenhomilie zu Tischa be-Aw. Leiden: Brill, 2007.

Goodman, M. Judaism in the Roman World. Leiden: Brill, 2007.

Grässer, E. “Der Hebräerbrief 1938-1963.” TR 30 (1964): 138-236.

Guthrie, G. "Hebrews' Use of the Old Testament: Recent Trends in Research." CBR 1.2 (2003): 271-294.

Haber, S. "Common Judaism, Common Synagogue? Purity, Holiness, and Sacred Space at the Turn of the Common Era." In McCready and Reinhartz, Common Judaism, 63-77.

Hare, D. R. A. "The Rejection of the Jews in the Synoptic Gospels and Acts." In Davies, Antisemitism, 28-32.

Harkins, P. W. St. John Chrysostom: Discourses Against Judaizing Christians. Washington D.C.: Catholic University of America Press, 1979.

Harrington, H. K. The Purity Texts. London; New York: T\&T Clark, 2004.

Hays, R. B. "'Here We Have No Lasting City': New Covenantalism in Hebrews.” In Bauckham et al., The Epistle to the Hebrews, 151-173. 
Hughes, G. Hebrews and Hermeneutics. Cambridge: Cambridge University Press, 1979.

Hurtado, L. W. One God, One Lord: Early Christian Devotion and Ancient Jewish Monotheism. 2nd ed., Edinburgh: T\&T Clark, 1998.

"Interactive Diversity: A Model of Christian Origins." JTS 64.2 (2013): 445-462.

Isaacs, M. E. Sacred Space: An Approach to the Theology of the Epistle to the Hebrews. JSNTSup 73. Sheffield: JSOT/Sheffield Academic Press, 1992.

Johnson, L. T. "The New Testament's Anti-Jewish Slander and the Conventions of Ancient Polemic." JBL 108.3 (1989): 419-441.

"The Scriptural World of Hebrews." Int 57 (2003): 237-250.

Joslin, B. C. Hebrews, Christ and the Law: The Theology of the Mosaic Law in Hebrews 7:1-10:18. Milton Keynes, UK: Paternoster, 2008.

Kim, L. Polemic in the Book of Hebrews: Anti-Judaism, Anti-Semitism, Supersessionism? Eugene, Oregon: Pickwick Publications, 2006.

Levine A.-J., and M. Z. Brettler, eds. The Jewish Annotated New Testament. Oxford: Oxford University Press, 2011.

Levine, L. I. The Ancient Synagogue: The First Thousand Years. Rev. ed., New Haven, Connecticut: Yale University Press, 2005.

- "'Common Judaism': The Contribution of the Ancient Synagogue.” In McCready and Reinhartz, Common Judaism, 27-46.

Lieu, J. “'The Parting of the Ways': Theological Construct or Historical Reality?” JSNT 56 (1994): 101-119.

Mackie, S. D. Eschatology and Exhortation in the Epistle to the Hebrews. WUNT II/223. Tübingen: Mohr Siebeck, 2007.

"Heavenly Sanctuary Mysticism in the Epistle to the Hebrews." JTS 62 (2011): 77117.

“Ancient Jewish Mystical Motifs in Hebrews' Theology of Access and Entry Exhortations.” NTS 58 (2012): 88-104.

Magness, J. The Archaeology of Qumran and the Dead Sea Scrolls. Grand Rapids, Michigan; Cambridge: Eerdmans, 2002.

McCready, W. O., and A. Reinhartz, eds. Common Judaism: Explorations in Second-Temple Judaism. Minneapolis, Minnesota: Fortress Press, 2008.

McKay, H. A. Sabbath and Synagogue: The Question of Sabbath Worship in Ancient Judaism. Leiden: Brill, 1994.

Migne, J.-P., ed. Patrologia Graeca. 161 vols, Paris: Migne, 1857-86.

Moffitt, D. M. Atonement and the Logic of Resurrection in the Epistle to the Hebrews. NovTSup 141. Leiden: Brill, 2011.

Nanos, M. D. "New or Renewed Covenantalism? A Response to Richard Hays." In Bauckham et al., The Epistle to the Hebrews, 183-188.

Neusner, J. Judaism and Christianity in the Age of Constantine. Chicago: University of Chicago Press, 1987.

—. "Judaism and Christianity in the Beginning: Time for a Category-Reformation?" BBR 8 (1998): 229-237.

Neusner, J., W. S. Green, and E. S. Frerichs, eds. Judaisms and their Messiahs at the Turn of the Christian Era. Cambridge: Cambridge University Press, 1987. 
Reich, R. Miqwa'ot (Jewish Ritual Immersion Baths) in Eretz-Israel in the Second Temple and the Mishnah and Talmud Periods. Ph.D. dissertation, Hebrew University of Jerusalem, 1990. [Hebrew].

Rowland, C., and C. R. A. Morray-Jones, The Mystery of God: Early Jewish Mysticism and the New Testament. CRINT 12. Leiden: Brill, 2009.

Royse, J. R. Scribal Habits in Early Greek New Testament Papyri. Leiden: Brill, 2008.

Ruether, R. R. Faith and Fratricide: The Theological Roots of Anti-Semitism. New York: Seabury Press, 1974.

Runesson, A. The Origins of the Synagogue: A Socio-Historical Study. Stockholm: Almqvist \& Wiksell International, 2001.

Runesson, A., D. D. Binder, and B. Olsson. The Ancient Synagogue from its Origins to 200 C.E. A Sourcebook. Leiden: Brill, 2008.

Sanders, E. P. Judaism: Practice and Belief, 63 BCE - 66 CE. Corrected ed., London: SCM; Philadelphia: Trinity Press International, 1994.

— . "Common Judaism and the Synagogue in the First Century." In Fine, Jews, 1-17.

—. "Common Judaism Explored." In McCready and Reinhartz, Common Judaism, 1123.

Schäfer, P. Judeophobia: Attitudes toward the Jews in the Ancient World. Cambridge, Massachusetts; London, England: Harvard University Press, 1997.

Schiffman, L. H. "The Early History of the Public Reading of the Torah." In Fine, Jews, 44-56.

Schwartz, S. Imperialism and Jewish Society 200 B.C.E. to 640 C.E. Princeton: Princeton University Press, 2001.

Segal, A. F. Two Powers in Heaven: Early Rabbinic Reports about Christianity and Gnosticism. Leiden: Brill, 1977.

Shanks, H., ed. Partings: How Judaism and Christianity Became Two. Washington D.C.: BAS, 2013.

Skarsaune, O. "Does the Letter to the Hebrews Articulate a Supersessionist Theology? A Response to Richard Hays." In Bauckham et al., The Epistle to the Hebrews, 174182.

Smith, J. Z. "Fences and Neighbours: Some Contours of Early Judaism." In Approaches to Ancient Judaism, edited by W. S. Greed, 1-25. vol. 2. Chico, California: Scholars Press, 1980.

Stemberger, G. "Was There a 'Mainstream Judaism' in the Late Second Temple Period?" Review of Rabbinic Judaism 4.2 (2001): 189-207.

Tönges, E. "The Epistle to the Hebrews as a 'Jesus Midrash."' In Gelardini, Hebrews: Contemporary Methods, 89-105.

van der Horst, P. W. "Was the Synagogue a Place of Sabbath Worship Before 70 CE?" In Fine, Jews, 18-43.

Wedderburn, A. J. M. "Sawing Off the Branches: Theologizing Dangerously Ad Hebraeos." JTS 56 (2005): 393-414.

Weiss, H.-F. Der Brief an die Hebräer. KEK 13. Göttingen: Vandenhoeck \& Ruprecht, 1991.

Wills, L. "The Form of the Sermon in Hellenistic Judaism and Early Christianity." HTR 77:3-4 (1984): 277-299.

Wilson, S. G. Related Strangers: Jews and Christians, 70-170 C.E. Minneapolis, Minnesota: Fortress Press, 1995. 